\title{
Almanya Türklerinin Dil Tutumları Üzerine Toplumdilbilimsel Bir Araştırma
}

\author{
Bertuğ Sakın \\ Sağlık Bilimleri Üniversitesi, İstanbul, Türkiye
}

Makale Bilgileri

Article Info:

Gönderim / Received: 12.09.2017

Kabul / Accepted: 26.01.2018

\footnotetext{
* Sorumlu Yazar / Corresponding Author: Sağlık Bilimleri Üniversitesi, İstanbul, Türkiye bertugsakin@gmail.com
}

\section{$\ddot{O} \mathbf{z}$}

Almanya'da yarım asrı geride bırakarak misafir konumundan yerleşik duruma geçen Türk toplumu, bu süreç zarfında sosyal, ekonomik ve kültürel bakımdan büyük değişimler yaşamıştır. Hâkim toplumun baskın kültürü sebebiyle uğradıkları değişimlerin yanı sıra Almanya Türklerinde farklı dilsel tutumlar da ortaya çıkmıştır. Bu dilsel tutumlar, nesiller arası farklılık göstermekle beraber aynı zamanda çeşitli sosyal sınıflara göre de şekil almaktadır. Bu araştırmada, Almanya Türklerinin göç süreçleri sonucunda ortaya çıkan dil tutumları, toplumdilbilim açısından ele alınmıştır. Bu bakış açısıyla Almanya Türklerinin dilsel tutumları; ana dile bakış açısı, Türkçeyi kullanma eğilimi, dil sürdürümü, dil tercihi, dil değiştirimi, Almancaya yaklaşımları, Türkçe hakimiyeti, ağızlara bakış açısı, dil kayması, genç kuşakların Türk edebiyatına yaklaşımları, Türkçe yayınlara eğilim, dil bağlamında entegrasyona yaklaşımları başlıkları altında incelenerek mevcut durum tespit edilmiş ve bu tutumlarda; yaşanılan eyalet, cinsiyet, nesil, doğulan ülke, eğitim durumu, vatandaşlık durumu, medeni hal, aylık gelir durumu, evde kimlerle yaşanıldığı, Almanya'da kalma süresi, eşin ve çocukların vatandaşlık durumu, katılımcının ve eşin konuşabildiği diller değişkenleri açısından tespit edilen farkl1l1klar ve bu değişkenlerin mevcut tutumlardaki etkileri ortaya konmuştur.

Anahtar Kelimeler: Toplumdilbilim, Göç, Dil Tutumları, Almanya’ya Türk İşçi Göçü.

\section{A Sociolinguistic Research on Language attitudes of German Turks}

\begin{abstract}
Turkish Society lived for almost more than one century in Germany and they became permanent residents rather than became visitors. Throughout this long period, they faced with significant changes in terms of social, economic and cultural aspects. Besides these changes due to dominant cultural environment they lived, they also adopted different language attitudes. This language attitudes differ depend on the generations while they also formed depend on different social classes. This research investigated the language attitudes of German Turks, which raised due to their migration period. From this perspective, German Turks' language attitudes, their approaches to the mother tongue, tendency to use Turkish language, language shifting and
\end{abstract}


maintenance, language preferences, approaches to the German language, ability of using Turkish literature, approaches of young generation to the Turkish literature, interest in Turkish publications, approaches regarding language integration were investigated. These aspects are considered based on the differences with respect to the state where people live, gender, generation, places where they were born, education levels, citizenship, marital status, monthly revenues, duration of living in Germany, with whom they live together, citizenship of couples and children in families and languages spoken by participants and his/her partners.

Keywords: Sociolinguistics, Migration, Language attitudes, Migration of Turkish workers to Germany.

\section{Giriş}

II. Dünya Savaşı sonrası gelişen sanayi atılımları neticesinde Almanya'da acil işgücü ihtiyacı ortaya çıkmıştır. İstihdam imkânı, yüksek maaşlar, kaliteli yaşam ve iş bulma kolaylığı gibi çekici faktörlerin yanı sıra 1950'li yıllarda Türkiye'deki yüksek işsizlik oranı, sosyo-ekonomik bunalımlar, kötü çalışma şartları ve düşük maaşlar gibi itici faktörlerin de neticesinde, Türkiye'den Almanya'ya 1960 öncesi öncü işçi göçleri başlamıştır. İlk aşamada küçük gruplar halinde gerçekleşen bu göçler, Türkiye ve Almanya arasında 1961 yılında imzalanan anlaşma ile kitlesel boyut kazanmış ve Türkler çalışmak için 1973 yılına kadar kafileler halinde Almanya'ya göç etmişlerdir. 1973 yılında Avrupa'da yaşanan petrol krizi sonucu Almanya, Türkiye'den göçmen işçi alımlarını durdurmuş olsa da 1980 yılına kadar aile birleşimi yoluyla Almanya'ya Türk göçü devam etmiştir. 1980 yılında Türkiye'de gerçekleşen askeri darbe sonucu Almanya'ya gidişler politik göç şeklini alarak devam etmiştir. 1983 yılında CDU iktidarının çıkarmış olduğu "Geri Dönüş Teşvik Yasası" sonucu Türklerin bir kısmı Türkiye'ye geri dönmüşse de beklenenin aksine Türkiye'den Almanya'ya göçler artarak devam etmiştir. 1990'lı yıllarda ise Almanya'ya Türk göçü evlilik yolu üzerinden devam etmiştir.

1991 yılında çıkarılan yabancılar yasasının Almanya'da yaşayan Türklerin sosyo-politik durumları üzerindeki etkisi büyük olmuştur. $\mathrm{Bu}$ kanunla beraber özellikle ikinci nesil Türkler yoğun şekilde Alman vatandaşlığına geçmişlerdir. $\mathrm{Bu}$ durum Almanya'daki Türklerin Alman toplumu içerisinde siyasi, ticari, sosyal ve kültürel alanlarda daha aktif rol alabilmesini sağlamış ve kendi gettolarında yaşadıkları izole hayattan kurtularak sosyal hayata katılımlarını hızlandırmıştır. 2000'li yıllara gelindiğinde Türkler Almanya'da birinci, ikinci ve üçüncü nesli bünyesinde barındıran, sosyalizasyon sürecini tamamlamış, toplumsal hayatın her kademesinde kendine yer edinmiş, Federal Meclis'te onlarca milletvekili ile temsil edilen bir topluluk halini almıştır. Alman İstatistik Dairesi'nin "Zensus 2011" istatistik araştırmasına göre Almanya'daki Türkiye kökenlilerin toplam sayısı 2.956.000'dir. $\mathrm{Bu}$ oran ile Türkler toplam Almanya nüfusunun \%3.6'sını oluşturmaktadır.

Kişilerin yaşamları boyunca maruz kaldı ğı çeşitli etkenler, sosyo-ekonomik değişimler ve ait oldukları toplumun temel dinamikleri onların dilsel tutumları üzerinde etkilidir (Balc1, Uyar ve Büyükikiz, 2012, s. 969). Almanya'da yarım asrı geride bırakarak misafir konumundan yerleşik duruma geçen Türk toplumu, bu süreç zarfında sosyal, ekonomik ve kültürel olarak büyük değişimler yaşamış ve bu durum Almanya Türklerinde farklı dilsel tutumların oluşmasına sebebiyet vermiştir. $\mathrm{Bu}$ dilsel tutumlar, nesiller arası farklılık göstermekle beraber aynı zamanda çeşitli sosyal sınıflara göre de şekil almaktadır. Bu araştırmada, Almanya Türklerinin yarım asırlık göç süreci sonucunda ortaya çıkan dil tutumları; toplumun dille ve dilin de toplumla olan ilişkisini inceleyen ve malzemesi toplumların dilsel davranışları olan "Toplumdilbilim” (Öztürk Dağabakan, 2012, ss. 87-89) açısından ele alınmıştır. Bu bakış açısıyla Almanya Türklerinin dil tutumları; ana dile bakış açısı, Türkçeyi kullanma eğilimi, dil sürdürümü, dil tercihi, dil değiştirimi, Almancaya bakış açısı, Türkçe hakimiyeti, ağızlara bakış açısı, dil kayması, genç kuşakların Türk edebiyatına yaklaşımları, Türkçe yayınlara eğilim, dil bağlamında entegrasyona bakış açısı başlıkları altında incelenerek mevcut 
durum tespit edilmiş ve bu tutumlarda; yaşanılan eyalet, cinsiyet, nesil, doğulan ülke, eğitim durumu, vatandaşlık durumu, medeni hal, aylık gelir durumu, evde kimlerle yaşanıldığ Almanya'da yaşama süresi, eşin ve çocukların vatandaşlık durumu, katılımcının ve eşin konuşabildiği diller değişkenleri açısından tespit edilen farklılıklar ve bu değişkenlerin mevcut tutumlardaki etkileri ortaya konmuştur.

\section{Yöntem ve Bulgular}

Çalışmanın araştırma tekniğini "İlişkisel Tarama Modeli" oluşturmaktadır. Alan araştırması için Almanya'da Türklerin en yoğun olarak yaşadığ 1 Nordrhein Westfalen, Baden Württemberg, Bayern ve Berlin eyaletlerinden eşit sayılarla ve cinsiyet, yaş, eğitim durumu, vatandaşlık durumu, aylık gelir durumu, medeni hal vb. farklı kriterlere sahip toplumun her kesiminden olacak şekilde, birinci, ikinci ve üçüncü nesilden 1.226's1 erkek, 823'ü kadın toplam 2.049 kişi üzerinde beşli likert ölçeğine göre düzenlenen ve 38 sorudan oluşan araştırma anketi uygulanmış, elde edilen veriler, SPSS 22 istatistik programına işlenmiş, yüzde, frekans ve ki-kare analizleri çıkartılmış, sonuç kısmında da mevcut bulgular yorumlanmıştır.

\section{Almanya'ya Türk İşgücü Göçü}

Almanya; Türkiye ile olan tarihsel bağları, acil işgücü ihtiyacı, yüksek ekonomik imkanları, iş bulma kolaylığı ve yaşam standartlarının yüksekliği gibi çekici faktörlerden dolayı, Türkiye'deki işçiler açısından her zaman Avrupa'da en çok tercih edilen ülke durumunda olmuştur. 1960 - 1994 yılları arası Avrupa'ya Türk işçi göçünün yaklaşık olarak \%50-\%75 aras1 Almanya'ya gerçekleşmiştir (Faist, 2003, s. 90). Türkiye'den yurt dışına modern anlamda ilk kitlesel işçi göçü 1961'de Almanya'ya olmuştur. Bundan sonra gerçekleşen Türkiye'den yurt dişına kitlesel işçi göçleri sırasıyla; 1964'te Almanya, Avusturya, Belçika ve Hollanda'ya, 1965'te Fransa'ya, 1967'de İsveç ve Avustralya'ya, 1975'te de Libya'ya olmuştur (Arayıc1, 2002, s. 44). Bu dönemlerde Türkiye'den yurt dışına göçte itici faktörler; işsizlik ve istihdam sorunu, iç göç ve yarattığı sosyo-ekonomik ve kültürel bunalımlar, kötü çalışma şartları, yetersiz maaş ve iş imkânı ile sosyal hakların azlığı şeklinde özetlenebilir (Göksu, 2000, s. 24). Ayrıca 1960 askeri darbesi, hükümetin batılılaşmayı hızlandırmak amacı ile yurt dışına işgücü gönderimi sonucu ülke içi işsizlik oranını düşürme beklentisi, gidecek işçilerin ülkeye getirecekleri döviz ve geri döndüklerinde kalifiye işçi olarak hizmet edecekleri düşüncesi de bu göçe Türk hükümeti tarafından zemin hazırlanmasında etkili olan unsurlardır (Karagöz, 2001, s. 21). Genel hatlarıyla Almanya’ya Türk göçünü şu başlıklar altında inceleyebiliriz:

\section{1. Öncü göçler (1961 öncesi)}

Almanya'ya modern anlamda ilk Türk işgücü göçü, 1956 yılında Kiel Üniversitesi Dünya Ekonomisi Enstitüsünün, Federal Almanya'nın Türkiye'ye yatırım yapması ve bu yatırımlarla Almanya'da ustabaşı olarak yetişmiş lise mezunu Türklerin istihdam edilmesi önerisi üzerine gerçekleşmiştir. İlk işgücü anlaşması Türkiye Dışişleri Bakanlığ ile Schleswig-Holstein Çalışma Bakanlığı arasında 1957'de imzalanmıştır. $\mathrm{Bu}$ anlaşma sonucu Türkiye'de yetişmiş ve mesleki eğitim görmüş, alanında uzman 12 kişilik bir zanaatkar grubu, aileleriyle birlikte Kiel'e gitmişlerdir. Bu ilk öncü grubun gidişinin ardından, bireysel imkanlarla, Almanya'ya küçük grupların göçleri başlamıştır. $\mathrm{Bu}$ ilk göçler neticesinde, yavaş yavaş Türkiye ile Almanya arasında işçi gönderimi üzerine bağlar kurulmaya başlamıştır. Örneğin; Almanya'da bulunan Türk iş adamları, sahip oldukları işletmelerde çalıştırmak üzere, Türkiye'den, ihtiyaç duydukları alanlardaki sanat okulu öğrencilerini, Almanya'ya staj yaptırmak üzere getirmeye başlamışlardır. Türkiye-Almanya arasındaki işçi trafiğini fark eden girişimciler tarafindan kurulan arac1 kuruluşlar, Alman firmalarının talepleri doğrultusunda Türkiye'den, özellikleri önceden belirlenmiş işçileri Almanya'ya çalışmak üzere getirmeye başlamışlardır. Tercüme ve İş Bulma adlı bu kuruluşlar ihtiyaç sahibi firmalara bu dönemlerde işçi teminine başlamıştır. Ayrıca Hamburg Zentralverband des Deutschen Handweks ile Türkiye Esnaf ve Sanatkârlar Konfederasyonu arasında sağlanan iş birliği ve Hamburg Türk- 
Alman Ekonomik İlişkiler Araştırma Enstitüsü sayesinde de Türkler Almanya'ya, isimle çağrılmak suretiyle, işçi olarak gitmeye başlamışlardır. 1961 'de Türkiye ile Almanya arasında imzalanan işgücü anlaşmasından sonra Almanya'ya işçi göçünün resmi olarak ve kitlesel boyutlarda başlamasıyla, bu gibi aracı kurumlar vasıtasıyla gerçekleştirilen sınırlı sayıda ve küçük gruplar halindeki işçi teminlerine, Almanya tarafindan son verilmiştir (Şahin, 2010, s. 36; Abadan Unat, 2002, s. 18).

\subsection{Kitlesel göçler (1961-1973 arası)}

1960 yılına kadar Almanya'ya işçi göçü, kişisel çabalarla ya da aracı şirket, kuruluş ve firmalar vasıtasıyla, kısıtlı sayıda gerçekleşmekteydi. Federal Almanya'ya Türk işgücü göçü, Türkiye ile Almanya arasında imzalanan 30 Ekim 1961 tarihli ve "505-83 SZV/3-92-42" say1lı anlaşma ile sistemli ve kitlesel göç halini almıştır. İki ülke arasında imzalanan ve 12 maddeden oluşan bu anlaşma, genel olarak Türkiye'den getirilecek işçilerin seçimleri, Almanya'ya sevk edilmeleri, işlemler sırasında Türkiye ve Almanya'nın sorumlulukları konularını kapsamaktaydı. Buna göre Türk tarafinca Türkiye'de irtibat büroları açılacak ve başvuran işçi adayları arasında ilk elemeler yapılarak seçilen uygun adaylar irtibat bürolarına yönlendirilecekti. İlk elemeden geçen adaylar, Alman tarafının yapacağı ikinci elemeye alınacak, işçi adayları gruplar halinde Alman doktorlar tarafından sağlık kontrollerinden geçirilecek, gerekli koşullara sahip olduğu belirlenen adaylardan uygun görülenler, Alman tarafinca seçilerek Almanya'ya gönderilecekti (Çi1, 2011, s. 44). İlk giden öncü gruba üç ile beş sene arası geçici oturma ve çalışma izni verilmişti. Ailelerini getirme ve sonradan birleşme hakkı da tanınmadığı için 1960'lı yıllarda Almanya'ya giden ilk işçiler genellikle bekar genç erkeklerden oluşmaktaydı. 1960'lı yılların sonuna doğru ise Almanya'nın ihtiyacı doğrultusunda çeşitli sektörlerden Türk kadınları da Almanya'ya işçi olarak gitmeye başlamışlar ve Almanya'daki birinci nesli oluşturmuşlardır (Tekin ve Hasskamp, 2011, s. 167; Faist, 2003, s. 122; Akkaya, 2011, s. 199).
Türkiye İş ve İşçi Bulma Kurumu verilerine göre 1961 yılında, Türkiye'den Almanya'ya, kişisel imkanlar ya da aracı kurumlar vasıtasıly giden 1.430'u erkek ve 46'sı kadın olmak üzere toplamda 1.476 kişi vardır. Bu sayı Türkiye ile Almanya arasında imzalanan işgücü anlaşması sonucu, 1962 yllında, 10.493'ü erkek ve 532'si kadın olmak üzere toplamda 11.025 kişiye ulaşarak kitlesel göç halini almıştır. İlk gidenlerin Almanya'ya yerleşerek çalışma hayatına başlamaları, yüksek ücretler elde etmeleri ve bunun Türk kamuoyunda dikkat çekmesi sonucu, Türkiye'deki işçiler daha yüksek oranlarla Almanya'ya işçi olarak gitmeye başlamışlardır. 1963 'te Almanya'ya gönderilen işçi sayısı 23.436'dır. Bu oran 30.04.1964 tarihinde Türkiye ile Almanya arasında imzalanan sosyal güvenlik sözleşmesi sonrası daha da artarak 54.902'ye ulaşmıştır. 1967 ve 1971'de Avrupa'daki ekonomik sorunlardan dolayı işçi akımı yavaşlamış ise de sonraki yıllarda yeniden artarak devam etmiştir. 1969 yılında Türkiye'den Almanya'ya giden iş̧i sayısı 98.142'dir. En yüksek oranlı kitlesel göç ise 1973 yılında gerçekleşmiştir. $\mathrm{Bu}$ tarihte Türkiye'den Almanya'ya göç eden işçilerin sayısı 103.793'tür. 1961 yılında Almanya'ya sadece 46 kadın işçi gitmişken, 1973 yılında Almanya'ya giden kadın işçilerin sayıs1 24.267'dir. Kitlesel göç dönemi olan 1961-1973 yılları arası Türkiye'den Almanya'ya çalışmak için gönderilen toplam işçi sayısı; 457.301'i erkek, 125.258'i kadın olmak üzere toplamda 582.559 kişidir.

\subsection{Aile göçleri (1973-1980 arası)}

15 Ekim 1973 tarihinde Petrol İhraç Eden Arap Ülkeleri Birliğinin (OAPEC) ambargosu sonucu Avrupa'da büyük bir petrol krizi yaşanmıştır. $\mathrm{Bu}$ petrol krizi ve devamında yaşanan ekonomik bunalım sonucu fabrikalar kapanmaya, işletmeler iflas etmeye başlamıştır. Bunun üzerine Avrupa ülkeleri yabancı işgücü ithalini durdurma kararı almıştır (Taşdelen, 2000, s. 5).

23 Kasım 1973'te Almanya, Avrupa Birliğine üye olmayan ülkelerden işçi alımını durdurmuştur. $\mathrm{Bu}$ tarihten sonra, Türkiye'den Almanya'ya başlayan kitlesel işçi göçleri büyük oranda azalma 
göstermiştir. Türkiye İş ve İşçi Bulma Kurumu verilerine göre 1961-1973 y1lları aras1 Türkiye'den Almanya'ya işçi olarak toplam 582.559 kişi gönderilirken, bu oran 1974-1980 yılları arası toplamda sadece 9.412 kişidir. Petrol krizi döneminde yabancı işçilerin toplu olarak fabrikalardan çıkarılması, Almanya'da yaşayan Türk işçileri kendi iş yerlerini kurmaya itmiştir. $\mathrm{Bu}$ durum onların toplumsal statülerini de etkilemiş ve Almanya'da misafir oldukları düşüncesini yavaş yavaş değiştirmeye başlamıştır. Almanya'ya kitlesel Türk işçi göçü 1973'te son bulmasına rağmen Almanya'daki Türk nüfusunda büyük bir azalma olmamış, aksine ilerleyen yıllarda Türklerin sayısı katlanarak çoğalmaya devam etmiştir. 1980 y1lına gelindiğinde Almanya'daki Türk nüfusu 1.462 .400 kişiye ulaşmıştır. Bu tarihlerde Almanya'da Yunanlıların sayıs1 193.500, İspanyolların sayısı ise 77.800 kişi azalmıştır (Aslan, 1996, s. 6).

1973 yılında Almanya'nın ithal işçi alımını durdurmas1 sebebiyle, bu tarihten sonra Türkiye'den Almanya'ya göç, aile birleşimleri yoluyla gerçekleşmiştir. Almanya'daki Türklere tanınan aile birleşimi hakkı sonucu, Almanya'daki Türk işçiler, Türkiye'de bulunan eşlerini ve çocuklarını, bu yolla Almanya'ya getirmeye başlamışlardır. Aile birleşimleriyle beraber artık Almanya'da Türk nüfusu kalıcı özellik göstermeye başlamıştır. Türkler, 1980'li yıllardan itibaren Türkiye'ye geri dönme fikrinden vazgeçerek Almanya'ya kalıcı olarak yerleşmişlerdir (Akkaya, 2011, s. 199; Alkan, 2011, s. 180; Kartal Doyuran, 2004, s. 21; Köksal, 1986, s. 112).

\subsection{Politik göçler (1980-1990 arası)}

Türkiye'den Almanya'ya göç akımı, 1980 yılında Türkiye'de yapılan askeri darbe ve devamında ülkede oluşan siyasi kaos sonucu "Politik Göç" şeklini almıştır. Buna göre 1980-1990 yılları arası Almanya'ya Türkiye'den toplam 158.263 siyasi sığınma talebi yapılmıştır. Darbe sonrası yaşanan politik göçlerle Türklerin sayısı Almanya'da giderek artmaya devam etmiştir (Akkaya, 2011, s. 199). Öncü göçlerden politik göçlere kadarki süreçte, her y1l nüfusunu artıran Türkler, 1980'li y1llara gelindiğinde, kendilerinden daha önce Almanya'ya göç etmeye başlamış olan diğer yabancilar arasında sayıca öne geçmeye başlamışlardır. Alman İstatistik Dairesinin verilerine göre 1980 yılında Almanya'da bulunan toplam yabanc1 sayısı 4.453.308 kişidir. Yabanc1ların genel nüfusa oranı ise \%7.2'dir. Türklerin sayıs1 1.462.400'dür. Bu tarihte Türkler Almanya'da yaşayan yabancıların toplam nüfusunun \%32.8'ini oluşturmaktadır. 1990 yılına gelindiğinde ise Türklerin sayısı 1.694.649 kişiye ulaşmış ve yabancı nüfusun \% 31.7'sini oluşturur hale gelmiştir.

Almanya'da yabancı işçi sayısının fazlalığı, geri dönmesi planlanan işçilerin Almanya'ya yerleşmeleri ve aile birleşim hakkından faydalanarak eşlerini ve çocuklarını da getirmeleri üzerine, 1 Kasım 1983 yılında, CDU iktidarı "Geri Dönüş Teşvik Yasası" nı çıkarmıştır. Bu yasa 30 Haziran 1984 yılına kadar göçmenlerin ülkelerine geri dönmeleri yönünde uygulanmıştır. Yasa neticesinde Almanya'da bulunan Türklerin bir kısmı Türkiye'ye kesin dönüş yapmışlardır. Fakat yapılan teşvik ve yardımlara rağmen Türklerin geri dönüş oranı, Almanya'daki nüfus artış hızlarına göre oldukça azdır. Teşvik yasasının uygulandığı yılda yaşanan geri dönüşlerden sonra, 1985 y1lından itibaren Türkler, Almanya'da sayılarını aile birleşimi yoluyla artırmaya devam ettirmişlerdir. Hatta geri dönüş teşvik yasasının uygulandığı yıllarda bile, aile birleşimleri yoluyla Türkler Almanya'ya gelmeyi sürdürmüşlerdir. 1983 yılında 27.800 kişi, 1984 y1lında ise 14.400 kişi aile birleşimi yolu ile Almanya'ya gelmiştir. 1985 yllından sonra ise artık Almanya'daki misafir işçiler, bu adlandırmadan kurtularak göçmenlik statüsüne kavuşmaya başlamışlardır (Şen ve Goldberg, 2004, s. 20; Şen, Ulusoy ve Öz, 1999, s. 41; Aslan, 1996, s. 6).

\subsection{Evlilik göçleri (1990 sonrası)}

1990 yılına gelindiğinde artık Türkiye'den Almanya'ya iş̧̧i göçü tamamen durmuş, aile birleşimleri tamamlanmış ve Türkler Almanya'ya misafir işçi olarak geldikleri ilk dönemlerdeki Alman toplumundan izole yaşadıkları hayata son vererek hâkim toplumla yakın ilişkiler kurmaya 
başlamışlardır. 1 Ocak 1991 yılında çıkarılan yabancılar yasası Almanya'daki Türklerin toplumsal hayata katılımlarında ve Almanya'daki konumlarında çok önemli bir yere sahiptir. $\mathrm{Bu}$ yasa ile Almanya'daki yabanciların Alman vatandaşlığına geçişleri kolaylaşmıştır. Bu tarihten itibaren özellikle ikinci nesil yoğun olarak Alman vatandaşlığına geçmeye başlamıştır. Vatandaşlık hakk1 alan Türkler, Alman siyasi hayatında da varlık göstererek toplumsal yaşama katılımlarını artırmışlardır (Kılıçaslan, 2006, s. 58; Şen vd., 1999, s. 19).

Alman vatandaşlığına geçişle birlikte siyasi ve sosyal hayatın yanında iş hayatında da daha fazla hak elde eden Türkler, ekonomik olarak daha yüksek standartlara sahip olmaya başlamışlardır. Giderek daha fazla işletme sahibi olan Türkler, 1990 yılından itibaren artık Almanya'da iş arayan konumundan işveren konumuna geçiş yapmışlar, kendi işletmelerini kurmuşlar ve Almanya'da istihdam oluşturmaya başlamışlardır. Sosyal, siyasi ve ekonomik anlamda güçlenen Türklerin sayıs1 1990 yılından sonra da Almanya'da artmaya devam etmiştir. 1990 sonrası Türkiye'den Almanya'ya göçler, evlilik yoluyla devam etmiştir. Almanya'da çalışan ya da kendi işyerine sahip olan Türkler, Türkiye'den evlilik yoluyla Almanya'ya ithal gelin ve damatlar getirmeye başlamışlardır (Akkaya, 2011, s. 199).

\section{Almanya Türklerinin Dilsel Tutumları}

Crystal'in "An Encyclopedic Dictionary of Language and Languages" adl 1 eserinde de belirtildiği üzere dil tutumu; bireylerin sahip oldukları ana dile ya da başka dillere karşı düşünceleridir. $\mathrm{Bu}$ düşünceler olumlu ya da olumsuz yönde olabilir. Dilsel tutum farklı dil değişkenlerine karşı gösterilen duygusal, bilişsel veya davranışsal tepkilerdir (Ryan, Giles ve Sebastian, 1982, s. 7). Almanya'da geçirdikleri sürenin sonunda Türklerin sosyal, ekonomik ve kültürel durumlarıyla beraber dilsel tutumlarında da farklılaşmalar meydana gelmiştir Doğup büyüdüğü topraklardan, kendine yabancı bir kültüre, dine ve dile sahip başka bir ülkeye göç eden ve göç ettiği ülkede yarım asrı geride bırakan bir topluluk elbette ki toplumdilbilimin araştırma sahası içinde oldukça önemli bir yere sahiptir. Dilbilimin alt disiplini olan toplumdilbilim, adından da anlaşılacağı üzere toplumun dille olan ilişkisini araştırır ve malzemesini de insanın dil kullanımı oluşturur (Öztürk Dağabakan, 2012, s. 87-89). Dil, canlı bir varlık olması ve sürekli değişim halinde bulunmasıyla beraber aynı zamanda da sosyal bir unsurdur (Bavelas ve Gerwing, 2007, s. 284). Her toplumsal unsur gibi dil de içinde bulunduğu toplumun özelliklerine göre şekil alır ve sosyal etkenlere göre kendini yeniler (Akarsu, 1984, s. 80). Oluşan bu yeni unsurlar, dilin ait olduğu topluluğun özelliklerine göre farklılıklar gösterebilir. Bernstein'ın "Eksiklik Kuramı (Defizithypothese)"na göre aynı toplum içinde bulunan insanlar, ait oldukları tabakaya göre dilsel farkl111klar göstermektedir (Heger, 2010, s. 3). Genel hatlariyla tutum; eğilimler, duygular, korkular ve inançların etkisiyle gelişen davranışlar bütünüdür (Thurstone, 1928, s. 531). Dilsel tutum ise bireylerin dil değişkenlerine karşı ortaya koydukları değerlendirmelerdir (Ryan vd., 1982, s. 7). Crystal'e göre bu değerlendirmeler; kişi, toplum, çevre ve sosyal tabaka gibi çeşitli etkenlere göre olumlu ya da olumsuz şekilde olabilir.

Kişilerin yaşamları boyunca maruz kaldıkları çeşitli etmenler, sosyal durumları, ekonomik gelişimleri ve ait oldukları toplumun temel dinamikleri onların dilsel tutumları üzerinde etkilidir. Çünkü tutumlar insanlarda doğumla kazanılmaz, aksine sonradan öğrenilir (Balcı vd., 2012, s. 969). Kişinin yaşamı boyunca edindiği bu dilsel tutumlar, dilin sürekli değişen ve gelişen yapısına doğru orantılı olarak, zaman içerisinde ve çeşitli etkenler neticesinde değişikliklere uğramaktadır. $\mathrm{Bu}$ etkenler genel olarak konuşucunun içinde bulunduğu etnik topluluk, yaş, eğitim, cinsiyet ve iletişim ortamı şeklinde kendini gösterir (König, 1992, s. 25). Bundan dolayı geçirdiği yarım asırlık süreç sonrasında elbette ki Almanya Türklerinin dil özeliklerinde de çeşitli farklılıklar oluşması son derece doğaldır.

$\mathrm{Bu}$ araştırmanın temelini oluşturan anketin sonuçları analiz edildiğinde; Almanya Türklerinin büyük çoğunluğunun ana dilleri olarak hala 
Türkçeyi gördükleri, çift ana dili olduğunu düşünmedikleri fakat iki dilli olmanın da bir avantaj olduğu görüşüne sahip oldukları tespit edilmiştir. Bununla beraber katılımcılar Türkçeyi daha çok evde aileleriyle iletişimde kullandıklarını belirtmişlerdir. Ana dili kullanım sıklığı maddelerine verilen cevaplarda katılımciların büyük çoğunluğunun Türkçeyi hemen her gün kullandıkları ve bu kullanımın daha çok sözlü olarak gerçekleştiği tespit edilmiştir. Ayrıca katılımcılar diğer Türk aileleriyle s1k s1k görüştüklerini ve bu görüşmelerde de Türkçe konuştuklarını belirtmişlerdir. Araştırmaya katılanların çoğunluğu Türkiye ile sıkı ilişki içindedir. Katılımcılar sik sik Türkiye'ye gittiklerini ve bundan dolayı Türkiye ile bağlarının güçlü olduğunu belirtmişlerdir. Ayrıca ana dillerinin yaşatılması açısından Almanya'da bulunan Türk derneklerinin çok önemli olduğunu düşünmektedirler. Yine Almanya'daki okullarda okutulan Türk Kültürü derslerinin Türkçenin devamlılığı açısından önemli olduğunu belirtmişlerdir. Diğer bir maddede katılımcılar büyük oranda çocuklarıla Türkçe iletişim kurduklarını ve gelecekte de iletişimde Türkçeyi tercih edeceklerini belirtmişlerdir. Fakat bu durumun Alman toplumundan kopuk yaşamak anlamına gelmediği ve içinde bulundukları toplumdan kopuk yaşamanın da Türkçeyi korumayacağı yönünde bir düşünceye sahip oldukları tespit edilmiştir.

Araştırmaya katılanların büyük çoğunluğu arkadaş çevrelerinin genellikle Türklerden oluştuğunu, kendilerini Türkçe daha rahat ifade ettiklerini ve öfke, sevinç, şaşkınlık gibi duygusal durumlarda kullandıkları ilk dilin Türkçe olduğunu belirtmişlerdir. Uygulanan frekans analizinin sonuçlarına göre araştırmanın örneklemini oluşturan katılımcıların büyük çoğunluğunun günlük konuşmalarda Almanca-Türkçe arasında ani geçişler yaptı̆̆ saptanmıştır. Ayrıca katılımcılar, Türklerin öncelikle Türkçeye hâkim olmaları gerektiğini ve yeni nesillerin ilk olarak kendi ana dillerini öğrenmelerinin zaruri olduğunu belirtmişlerdir. Ankete katılan kişilerin büyük çoğunluğu kendi ana dillerinin iyi düzeyde olduğunu fakat gelecek nesillerin Türkçeye hakimiyetlerinin daha zayıf olacağını düşünmektedir. Yine elde edilen sonuçlara göre Almanya Türkleri arasında, gençlerin konuşurken daha fazla hata yaptığı, Türkler arasında bölgesel ağızların kullanımının -gençlerde daha az olmak kaydıyla- yaygın olduğu ve bu ağız varlığının Türkçenin zenginliğini gösterdiği görüşü hakimdir. Ayrıca katılımcıların Türkçenin gelecekte Almanya içinde unutulmayacağı ve yeni nesillerin ana dillerinin Almanca olmayacağ 1 görüşünde olduğu tespit edilmiştir. Anketin son bölümündeki sorulara verilen cevaplar incelendiğinde ise Almanya'daki Türk gençlerinin Türk Edebiyatını ve yazarlarını yeterince tanımadıkları düşüncesinin katılımcılar arasında yaygın olduğu ortaya çıkmaktadır. Ayrıca katılımcıların büyük çoğunluğu sıklıkla Türkçe yayın yapan televizyon ve radyo kanallarını takip ettiklerini ve yine Türkçe yayımlanan dergi, gazete ve kitapları okuduklarını belirtmişlerdir. Son olarak dil- entegrasyon ilişkisi açısından değerlendirilen sonuçlara göre Türklerin eskiye oranla Alman toplumuyla birlikte yaşama fikrine daha olumlu yaklaştıkları ve Almanca dil becerisinin bu bağlamda bir avantaj olduğunu düşündükleri tespit edilmiştir.

\section{Sonuç ve Tartışma}

Bilindiği üzere eğitim seviyesi yüksek olan kişilerin ana dil bilinçleri de yüksek olmaktadır (Kipp'ten aktaran Çolak Bostanc1, 2014, s. 116). Bu mevcut durum Almanya Türklerinde de tespit edilmiştir. Almanya'da yarım asırlık bir süreci geride bırakan Türk toplumu, geçirmiş olduğu değişim ve maruz kaldığı tüm olumsuz etkenlere rağmen hala Türkçeyi ana dili olarak görmektedir. $\mathrm{Bu}$ yaklaşımda kişilerin dil, eğitim ve gelir durumu değişkenleri oldukça önemlidir. Elde edilen bulgular incelendiğinde; Almanya'daki Türkler arasında, yüksek eğitimli sınıfın düşük eğitimli sınıfa, birden fazla dil konuşabilenlerin sadece tek dil konuşabilenlere ve gelir durumu yüksek kişilerin alt gelir sınıfında olanlara oranla ana dil bilincinin daha yüksek olduğu söylenebilir. İki dilliliğe karşı olumlu yaklaşım, yine bu üç sosyal gruba mensup kişilerde, diğerlerine göre daha belirgindir. Kuşaklar arası fark ele alınacak olursa; birinci ve ikinci neslin ana dile bakış 
açıları üçüncü nesle göre daha olumludur. Elde ettiğimiz bu sonuç, Yağmur ve Akıncı'nın "Language use, choice, maintenance, and ethnolinguistic vitality of Turkish speakers in France: Intergenerational differences" adl1 çalışmalarında belirttikleri sonuçlarla da örtüşmektedir. Buna göre birinci ve ikinci nesiller çift ana dilleri olmadığını belirtirken üçüncü nesil Türkler çift ana dile sahip olduklarını ortaya koymuşladır. Ayrıca iki dilliliğin avantaj olduğu fikri üçüncü nesilde, birinci ve ikinci nesle göre çok daha baskındır. Elbette ki bu durumun ortaya çıkmasında üçüncü neslin Almanya'da doğup büyümüş olması, çok iyi Almanca bilmesi ile birinci ve ikinci nesilden farklı olarak Alman toplumuyla hayatın her alanında kaynaşmış olmasının da etkisi vardır.

Türkiye kökenli göçmenler Almanya'da yoğun dayanışma içerisindedirler. Yüzlerce dernek, sivil toplum kuruluşu ve organizasyona sahip olmaları, ticari ilişkilerini kendi aralarında yürütmeleri, dini ihtiyaçlarını ortak karşılama gereksinimi ve aynı mahallelerde yaşama istekleri gibi çeşitli nedenlerin yanı sira elbette yabancı bir toplumda yaşamanın getirdiği azınlık psikolojisi de onların daha çok bütünleşmesini, dayanışmasını ve iç içe olmalarını sağlamaktadır. Diğer Avrupa ülkelerine göre Almanya'da çok daha yoğun şekilde bir arada olan Türkler, elbette ki bu beraberliğin neticesinde Türkçeyi sadece ev ortamında değil, sosyal yaşam ve iş hayatında da yoğun olarak hemen her gün kullanmaktadır (Yağmur, 2010, s. 234). Almanya Türklerinin Türkçeyi kullanma eğilimleri oldukça yüksektir. Türkçeyi kullanım sıklığında cinsiyet, vatandaşlık ve dil bilme durumu önemlidir. Buna göre erkekler kadınlara, aylık gelir durumu düşük olanlar yüksek olanlara, Türk vatandaşlığı ve çifte vatandaşlık sahipleri Alman vatandaşlığına sahip olanlara, konuşabildikleri dil sayısı fazla olanlar az olanlara, eşi Türk vatandaşı olanlar eşi Alman vatandaşı olanlara göre Türkçeyi daha çok kullanma eğilimi içerisindedirler.

Ortak dili kullanan insanlar arasında ortak kültür özelliklerinin de olması doğaldır (Parekh, 2002, s. 185). Her ne kadar Türkler Alman toplumu içinde yaşıyor olsalar da Türk kültürünü ve onun yapısal özelliklerini güçlü şekilde bünyelerinde barındırmaktadırlar. Bu durum, Türk toplumunun sınıfsal yapısı ve kültürel durumu ile açıklanabilir. Türk toplumunun bireylerine dayattığ a ağır cinsiyet rolleri elbette ki kişilerin dilsel eğilimlerine de etki etmektedir (Ercan ve Yağcıŏglu, 2007, s. 1). Türk erkekleri ana dillerini koruma eğilimi içerisindedirler ve evde eşleriyle ya da çocuklarıyla genelde Türkçe konuşmaktadırlar. Türkçe Almanya'da en sık ev ortamında kullanılmakta ve yeni nesillerin ana dillerini öğrenmeleri de aile ortamında sağlanmaktadır (Baş, 2014, s. 82). Burada babanın ana dili ile kültürü koruma ve sürdürme içgüdüsü etkindir. Almanya'da yaşayan Türk vatandaşlarının çoğu, hakları olmasına rağmen Alman vatandaşlığına geçmek istemeyen kişilerden oluşmaktadır. Bunun temel sebeplerinden biri vatandaşlık değişimi ile milli kimlik, dil ve kültür kaybı yaşanabileceği korkusudur. Öyle ki Türk vatandaşlı̆̆ında kalanların ya da çifte vatandaşlığa sahip kişilerin Türkçeyi kullanma eğilimleri, Alman vatandaşlığına geçmiş kişilere oranla daha yüksektir.

Almanya'ya göçün ilk dönemlerinde Türklere verilen misafir işçi unvanı, onlarda uzun yıllar sürecek "Almanya'da geçici olma" algısını oluşturmuş̧ur. Bu anlayış sebebiyle Türkler, uzun y1llar boyunca Türkiye'ye geri dönme hayaliyle yaşamış ve bu durum onların hâkim dile yönelmelerini geciktirmiştir. Kuşaklar arası fark incelendiğinde Türkçeyi kullanma eğilimi, yoğun olarak birinci nesilde göze çarpmaktadır. En az oran ise üçüncü nesil Türklere aittir. Türkçenin kullanım alanlarına bakıldığında üçüncü nesil Türklerin Türkçeyi daha çok evde, birinci ve ikinci nesil Türklerin ise Türkçeyi evle beraber sosyal hayatlarında da sıklıkla kullandıkları görülmektedir. Bunun temel sebebi, birinci ve ikinci neslin genellikle sosyal çevrelerinin de Türklerden oluşuyor olmasıdır. Oysaki üçüncü nesil Türkler Alman toplumuyla daha sıkı ilişki içinde olduğu için sosyal çevreleri de birinci ve ikinci nesle oranla daha çok Türk olmayan kişilerden oluşmaktadır. Üçüncü neslin genellikle evde Türkçeyi kullanma eğiliminde bulunması bu 
durumun doğal bir sonucudur. Türkçeyi kullanma eğilimlerine etki eden diğer önemli bir faktör de eğitim durumudur. Daha önce de belirtildiği üzere, eğitimli kişilerin dil bilinçleri diğer kişilere göre daha ileri düzeydedir. Üniversite mezunu Türklerin Türkçeyi kullanma eğilimleri; ilkokul, ortaokul ve lise mezunlarına oranla daha yüksektir. Almanya Türklerinin Türkçeyi kullanma eğilimleri yüksek olmakla beraber bu eğilim daha çok sözlü dil üzerinedir. Birinci nesil Türkler, Türk dernek ve sivil toplum örgütlerinde, kahvehanelerde ve özellikle ibadet yerlerinde Türkçeyi sözlü olarak kullanırlar (Çolak Bostancı, 2014, s. 123). Türkçenin yazılı olarak kullanım alanlarının kısıtlılığı ve sosyal ortamda ya da ev ortamında Türkçe kullanımının yoğunlaşması elbette ki sözlü dili daha tercih edilir hale getirmiştir. İkinci ve üçüncü neslin sosyalleşmesi aile, okul ve arkadaş çevresinde gerçekleştiğinden, bu ortamlarda sözlü dilin tercih edilmesi de kaçınılmaz olmaktadır (Yıldız, 2012, s. 1). Ayrıca Türk gençleri ev ve sosyal ortamlarının haricinde kendi aralarında da Türkçeyi daha çok sözlü olarak kullanmaktadırlar (Adıgüzel, 2004, s. 221).

Azınlık dilleri bulundukları ülkelerin hâkim dillerine kayma eğilimi içindedir. Gerek günlük hayatın olağan akışında gerekse beraber yaşanılan toplumla sosyalleşme sürecinde etkin olan hâkim dildir. Göçmenler bu hâkim dile kayma eğilimine sahip olmakla beraber kimi zaman da bu etkinin neticesinde ana dillerini koruma eğilimi gösterirler (Yalınkılıç, 2013, s. 116). Almanya Türklerinde bu ikinci eğilim daha güçlü gözlemlenmektedir. Çeşitli Avrupa ve Balkan ülkeleri ile Amerika'da yaşayan Türkler üzerine yapılan araştırmaların sonuçları incelendiğinde, Türkçenin en çok Almanya'da etnik dilsel canlılığa sahip olduğu görülmektedir. Ayrıca Türkçe diğer azınlık dilleri arasında da en canlı dil olma özelliği taşımaktadır (Yağmur, 2010, s. 226). Bunun temel sebeplerinden biri de Almanya Türklerinin aile ortamında Türkçe konuşma eğilimleridir. Çünkü azınlık dillerinin sürdürümü açısından ana dilin evde konuşuluyor olması çok önemlidir (Yalınkılıç ve Yağmur, 2014, s. 294). Bireyler doğup büyüdükleri coğrafyalardan, çeşitli sebeplerle kendi dil ve kültürlerine yabancı farklı coğrafyalara göç edebilirler. Göç eden kişiler, gittikleri ülkelerde farklı dilsel topluluklar arasında yaşıyor olsalar bile kendi ana dillerini kullanmaya devam ederler. Bireylerin farklı dilsel topluluklar içerisinde ana dillerini kullanmaya devam etmelerine dil sürdürümü adı verilir (İmer, Kocaman ve Özsoy, 2011, s. 89). Dil sürdürümlerindeki en etkili unsurlar; nüfus dağılımı, yaş, doğum yeri, göç edilen ülkede yaşama süresi, cinsiyet, evlilik durumu, eğitim ve ağız kullanımıdır (Kipp, Clyne ve Pauwels, 1995, s. 117). Birinci ve ikinci kuşak Türkler yeni nesillerle Türkçe konuşma eğilimi göstermektedirler. $\mathrm{Bu}$ eğilim, eğitim seviyesi yüksek kişilerde çok daha fazla kendini göstermektedir. Yağmur "Language use and ethnolinguistic vitality of Turkish compared with the Dutch in the Netherlands" başliklı çalışmasında Hollandalı Türklerinin dil tutumlarını ortaya koymuş ve eğitimin dil sürdürümlerindeki önemini vurgulamıştır. Yüksek eğitimli kişiler hem ana dil bilincine sahiptir hem de yeni nesillere ana dillerini öğretmeye meyillidirler (Kipp'ten aktaran Çolak Bostanc1, 2014, s. 116). Nordrhein Westfalen ve Baden Württemberg eyaletlerindeki Türklerde bu eğilim en üst seviyededir. Almanya'ya ilk göç edilen ve Türklerin yoğun olarak yaşadıkları bölgeler olan Nordrhein Westfalen ve Baden Württemberg eyaletleri, sahip oldukları dinamik Türk nüfusu, bu nüfusun ana dil ve kültürlerine olan bağlılıkları ve dil sürdürümü açısından diğer eyaletlerden ayrılmaktadır.

Almanya Türklerinin; akrabalık bağları, tatillerde memleketlerine gidiyor olmaları, Türkiye ile ticaret ilişkileri ve sivil toplum kuruluşlarının faaliyetleri sebebiyle Türkiye ile olan bağları oldukça güçlüdür. Almanya Türkleri sıklıkla Türkiye'ye seyahat etmektedirler. Birinci nesil Türkler, geçmişten gelen bağları sebebiyle bu seyahatleri en çok yapan kitledir. Almanya'ya göç ederek doğup büyüdükleri topraklardan ayrılıp kendi dil ve kültürlerine yabancı başka bir ülkede yaşamaya başlayan Türkler, gerek hakim dili yeterince bilmemeleri, gerek yabanci bir ülkede olmalarının vermiş olduğu dayanışma içgüdüsü gerekse de çalıştıkları iş yerlerinin kendilerine 
tahsis etmiş oldukları konutların genelde aynı bölgelerde ve iç içe olması sonucu, gettolaşma olarak adlandırılan, hakim toplumdan kopuk şekilde bir arada yaşamaya başlamışlar ve zamanla kendilerine has Türk mahallelerini oluşturmuşlardır. Genellikle birinci ve ikinci neslin oluşturduğu ve bünyesinde düşük eğitimli bireyleri barındıran bu homojen bölgeler Almanya'da dil sürdürümünü olumlu yönde etkilemiştir. Hâkim topluluk içinde eriyip kaybolmak korkusu, kültürün ve dilin yok olacağ 1 endişesiyle birleşince, göçmen Türklerde dile daha fazla bağlanma, ana dili koruma ve kullanmay sürdürme refleksi oluşturmuştur (Myers Scotton, 2006, s. 90). Genel olarak mevcut durum bu şekilde de olsa, günümüzde Almanya Türkleri Alman toplumundan kopuk yaşamanın Türkçeyi koruduğunu düşünmemektedir. $\mathrm{Bu}$ araştırmanın sonucu göstermektedir $\mathrm{ki}$ artık Almanya Türklerinde geçmişten gelen hâkim toplumdan ayrı yaşama ve bu sayede dili ve kültürü koruma tutumu değişikliğe uğramıştır. $\mathrm{Bu}$ tutum değişikliğindeki en önemli etkenler, günümüzde artık Almanya'nın hemen hemen her bölgesinde bulunan Türk sivil toplum örgütleri, dernekler, ibadet merkezleri ve bunun gibi göçmen Türklerin dillerini ve kültürlerini kaybetmeyeceklerini hissettiren kuruluşların varlığıdır. Almanya Türklerinin Türk dernek ve kuruluşlarına sıkça gittikleri ve bu derneklere karşı olumlu tutum gösterdikleri belirlenmiştir. Adıgüzel' in 'Kimliğin Korunmasında ve Üretilmesinde Türk Derneklerinin Rolü Almanya / Köln Örneği” adlı doktora tezinde de bu durum detaylıca ortaya konmuştur. Nesiller arasında, bu dernek ve kuruluşların faaliyetlerine en sık katılan grup birinci nesil, en az katılan ise üçüncü nesildir. Türk derneklerine, erkekler kadınlara oranla daha çok gitmektedirler. Bunun sebebi Türk kültüründeki keskin cinsiyet rolleridir. Erkekler genellikle Türk kahvehaneleri ya da derneklerinde sosyalleşip ana dillerini kullanırken, kadınlar daha çok ev ortamında Türkçeyi kullanmaktadırlar. Türk derneklerine gidiş oranlarında en düşük seviye üniversite mezunları ve Almanya doğumlularda görülmektedir. Bu durum üniversite mezunlarının ve Almanya doğumlu kişilerin sosyal çevrelerinin, Türkiye doğumlu ve daha düşük eğitim seviyesine sahip bireylere oranla daha fazla Türk olmayan kişilerden oluşuyor olmasıyla ilgilidir. Buna rağmen araştırmaya katılanların büyük çoğunluğu Türkçenin yaşatılması ve sürdürülmesi konusunda Türk derneklerinin ve okullarda verilen Türk kültürü derslerinin çok önemli olduğunu belirtmişlerdir. Almanya Türkleri arasında dil sürdürümü en çok eğitim seviyesi yüksek katılımcılarda görülmektedir. Bireyin dil bilme durumu da dil sürdürümlerinde etkilidir. Birden fazla dil bilen kişilerin dil sürdürümlerinin de yüksek olduğu saptanmıştır. Ayrıca kültür merkezleri ve ibadet yerlerinde kullanılan dilin Türkçe olması da dil sürdürümünde olumlu bir etmendir (Çolak Bostanc1, 2014, s. 123).

Dil tercihi; çok dilli ortamda bulunan kişilerin yaş, cinsiyet, eğitim, toplumsal bask1, dilsel yeterlilik, sosyo-ekonomik durum gibi etkenler neticesinde diğer insanlarla iletişimlerinde diller ya da değişkenler arası tercih yapma durumudur. Kişiler böyle durumlarda bazen kendi dillerinin farklı değişkenlerini bazen de ana dilleri dışında bir dili tercih edebilirler (Yalınkılıç, 2013, s. 51; İmer vd., 2011, s. 89). Katılımciların dilsel tercihleri; aile ortamında, yakın arkadaş çevresinde ve sosyal hayatta olmak üzere değişiklik göstermektedir. Buna göre evde ve yakın arkadaşlarla iletişimde genellikle Türkçe tercih edilmektedir. Bu duruma benzer bulgular Baş'ın 'Federal Almanya'da Yayımlanan Türkçe Günlük Gazetelerin Dil Kullanımı Üzerine" başlıklı çalışmasında da ortaya konmuştur. Ayrıca bu noktada dikkat çeken başka bir konu, erkeklerin kadınlara göre çok daha az oranda sosyal ortamlarında Almancayı tercih ediyor olmasıdır. Kadınlar ve erkekler toplumsallaşma süreçlerinden dolayı farklı dilsel biçimler edinmektedirler. Buna göre erkeklerin sosyal ortamları kadınlara göre daha geniştir. Erkekler bu geniş sosyal ortamlarda büyük gruplarla rahatça konuşma eğilimi içerisindedirler (König, 1992, s. 34). Türk erkeklerinin sosyal çevrelerinin daha çok kendi ana dilini rahatça konuşabildiği ve kendilerini özgürce ifade edebildiği kişilerden oluşması doğaldır. Ayrıca Türkiye doğumlu bireylerin de ana dillerinde aynı şekilde özgürce konuşma eğilimi içerisinde 
olduklarını belirtmek gerekir. Erkek katılımcılar ve Türkiye doğumlu kişiler sosyal ortamlarında ana dillerini konuşmayı tercih etmektedirler. Ayrıca gelir seviyesi yüksek olan bireylerin dar gelirli kişilere oranla daha geniş ve çeşitlilik arz eden sosyal çevreleri bulunmaktadır. Bu sebeple gelir seviyesi yüksek kişiler de sosyal hayatlarında Almancayı tercih etmektedirler. Nesiller arası fark ele alındığında ise üçüncü nesil sosyal hayatında Almanca konuşmayı tercih ederken birinci nesil bunu reddetmektedir. Bu durumu ortaya koyan en önemli etmenler elbette ki üçüncü neslin Almanya'da doğup büyümüş olmas1, Almancaya hâkim olması ve sosyal çevrelerinin çoğunlukla Türk olmayan kişilerden oluşmasıdır.

Çift ana dile sahip kişilerin en çok hangi dile bağlı olduklarını, onların duygularını ifade ederken tercih ettikleri dil ortaya koymaktadır. Özellikle iki dilli insanlar için duyguların dili onların en bağlı oldukları dildir (Yalınkılıç ve Yağmur, 2014, s. 297). Katılımcıların büyük çoğunluğu öfke ve sevinç gibi duygusal durumlarda ilk olarak Türkçeyi tercih etmektedirler. Duygusal tepkimelerde Türkçe tercihi; Nordrhein Westfalen ve Baden Württemberg eyaletlerinde Berlin ve Bayern eyaletlerine oranla daha yoğun şekilde ortaya çıkmaktadır. Bu durum da yine bu iki eyalette bulunan Türklerin demografik özellikleri ve dilsel canlılık durumuyla açıklanabilir. Türklerin en yoğun olarak yaşadığı ve dilsel canlılığın en yüksek olduğu iki eyalet Baden Württemberg ve Nordrhein Westfalen eyaletleridir. Bunun yanında Türk göçmenlerin; vatandaşlık durumu, doğulan ülke, medeni hal ve dil bilme değişkenlerinin onların dil tercihlerinde oldukça etkili olduğu saptanmıştır. Buna göre Türkiye doğumlular, Türk vatandaşlığına sahip olanlar, evli kişiler ve birden fazla dil bilen bireyler bu tip anlık duygu artışlarında ilk olarak Türkçeye başvurmaktadırlar. Nesiller arası farka bakıldığında ise yine birinci neslin duygusal tepkilerinde üçüncü nesle oranla daha çok Türkçeyi tercih ettikleri anlaşılmaktadır.

Dil tercihlerinde kişilerin hâkim oldukları dil ön plana çıkmakla beraber, içinde bulunulan ortam da bu konuda etkilidir. Örneğin göçmen çocukları, ana dillerini evde ve genellikle yakın arkadaşlarıyla konuşmayı tercih ederler (Baker'den aktaran Y1ld1z, 2012, s. 160). Bu durum dilin öğrenildiği ortam ve kişiler ile alakalıdır. Çocuklar ana dillerini öğrendikleri kişiler ile ve ana dilin öğrenildiği ortamlarda yine ana dillerini kullanma eğilimi içerisine girmektedirler. Almanya Türklerinin evde sıklıkla Türkçe konuşmayı tercih etmelerinin bir diğer nedeni de bu şartlanmadır. Örneğin; Almanya'da doğmuş büyümüş bir Türk genci, Türkiye'den Almanya'ya gelmiş bir kişiyle, bu kişi çok iyi derecede Almanca konuşabiliyor olsa da, Türkçe konuşmayı tercih etmektedir. Oysaki bu genç kendini Almanca çok daha iyi ifade edebilmektedir ve karşısındaki kişinin de iyi derecede Almanca konuştuğunu bilmektedir. $\mathrm{Bu}$ durum bireyin Türkiye ve Türkçe şartlanmasıyla alakalıdır. Birey Türkiye'den gelen kişi ile Türkçe konuşmaya kendini şartlamıştır. Aynı durum ev ortamı için de geçerlidir. Kişi ana dilini ev ortamında ailesinden öğrendiği için, bu ortam onda Türkçe şartlanması oluşturmuştur. Katılımcıların kendilerini Türkçe ifade edebilme durumlarına baktığımızda, Nordrhein Westfalen ve Baden Württermberg eyaletlerinde yaşayan Türklerin Türkçe hakimiyetlerinin oldukça yüksek olduğu görülmektedir. Bu durum, daha önce de belirtildiği üzere, özellikle bu iki eyalette dilsel canlılığın yüksek olması ve Türkçenin ev, iş ve sosyal hayatta aktif olarak kullanılıyor olmasından kaynaklanmaktadır. Arkadaşları ağırlıklı olarak Türk olmayan kişilerden oluşan bireylerin Berlin eyaletinde yoğunlaştıkları tespit edilmiştir. Ayrıca bu eyalette Türklerin sayısı Nordrhein Westfalen ya da Baden Württemberg eyaletine göre daha azdır. Nordrhein Westfalen eyaletinde 512.703 Türk yaşarken Berlin eyaletinde bu sayı $110.558^{\prime}$ dir.

Dilsel topluluklar ortak bir dile sahip, ortak iletişim süreçlerini bünyelerinde barındıran kişilerden oluşmaktadır (Kocaman ve Osam, 2000, s. 43). Almanya'da yaşayan Türkler, ana dillerinin yanında, içlerinde yaşadıkları hâkim toplumun dilsel özelliklerini de bünyelerine katmışlardır. Türkçede olmayıp Almancada bulunan "Termin", "Krank", "Hauptbahnhof" gibi birçok kelime Almanya Türkleri tarafından günlük 
konuşmalarda sıklıkla cümle içinde kullanılmaktadır. Ayrıca yine Türkçe başlayan günlük konuşmalar bir anda Almancaya ve ardından yeniden Türkçeye dönüşebilmektedir. Konuşmalarda kelime ve cümle boyutunda yaşanan bu değişmeler, dil yahut kod değişimi (code switching) olarak tanımlanmaktadır (Eker, 2007, s. 127-129). Almanya Türkleri arasında özellikle üçüncü nesilde sıkça rastlanan bu durum, bireyin dile yeterince hâkim olmamasından kaynaklanmaktadır. Örneğin; kişi söze Türkçe başlamaktadır ama anlatmak istediği konu hakkında kullanması gereken bir kelime Türkçe kelime hazinesinde bulunmamaktadır. $\mathrm{Bu}$ durumda kişi Türkçesini bilmediği bu kelime yerine onu karşılayan Almanca kelimeyi kullanarak konuşmasını Türkçe sürdürmeye devam etmektedir. Yahut kişi Türkçe başladığı konuşmasına bir sonraki ifadesini Almanca daha iyi ya da daha akıcı anlatabileceğini düşündüğü için Almanca devam etmektedir. $\mathrm{Bu}$ dilsel değiştirimler, dilsel boşluk olarak tanımlanan kelime ya da cümle bazlı yetersizliklerin telafisi için kullanılmaktadır (Göktuna Yaylacı, 2012, s. 81). Genel tanımıyla dil değiştirimi; kişinin konuşma esnasında kullandığı dili bırakıp farklı bir dille konuşmasına devam etmesidir. Dil değiştirimindeki diller arası geçiş; cümle içi değişimler, cümleler arası değişimler ve amblematik değişimler şeklinde gerçekleşir. Özellikle iki dilli ortamlarda büyüyen bireylerde sıklıkla karşılaştığımız bu dil değiştirimlerinin sebebi kullanılan dildeki metinsel boşlukların doldurulma ihtiyacıdır (Göktuna Yaylacı, 2012, s. 68-81). Almanya Türkleri günlük konuşmalarında Almanca-Türkçe arasında ani geçişler yaparlar. Katılımcıların cevapları incelendiğinde, bu kod değiştirimlerinin diğer eyaletlere oranla en çok Berlin eyaletinde yaşayan Türkler tarafından yapıldığı tespit edilmiştir. Ayrıca Almanya doğumlu katılımcılarda dil değiştirimleri daha fazla görülmekte, en az kod değiştirimi ise Türk vatandaşı olan katılımcılarda görülmektedir. Dil bilme oranı arttıkça kişilerin dil değiştirim oranları da artmaktadır. Dil değiştirimini en az birinci nesil yapmaktadır. $\mathrm{Bu}$ oran üçüncü nesilde ise en yüksek seviyededir. Özellikle üçüncü nesil arasında, Almanca ve Türkçenin karıştırılarak birlikte kullanılması oldukça yaygındır (Yağmur, 2010, s. 235).

Katılımcıların Almancaya yaklaşımları ele alındığında, göçün ilk dönemlerine kıyasla, Almancaya bakış açısında değişim yaşandığı ortaya çıkmaktadır. Yıllar geçtikçe Almanya'da toplumsal hayatta daha aktif rol almaya başlayan Türkler, önceki dönemlerden farklı olarak, yeni nesillerin Türkçeden önce Almanca öğrenmesi ve öncelikle Almancaya hâkim olmaları gerektiği düşüncesinden vazgeçmişlerdir. Ana dil bilincinin Türk toplumu arasında gelişmesi, Türk sivil toplum örgütlerinin Türkçe ve Türk kültürü üzerine aktif çalışmaları, okullarda okutulan Türk kültürü dersleri, Türkçenin artık Almanya'da sadece evde kullanılan bir dil olmaktan çıkıp aynı zamanda ticari ve sosyal hayatta da kullanılmaya başlanması ve Almanya'da Türkçenin dilsel canlılığının artması gibi etmenler Almancaya bakışta bu değişimin yaşanmasına neden olmuştur. $\mathrm{Bu}$ bakış açısına en yüksek oranlarla sahip gruplar; üniversite mezunları, evli olan bireyler, birden fazla dil bilenler ve aylık gelir düzeyi yüksek olan kişilerdir. Grosjean'in "Life with two languages: An introduction to bilingualism" adl1 çalışmasına göre dilsel seçimlerde dış baskı önemli bir etkendir. Almanların bulunduğu sosyal ortamlarda özellikle iyi derecede Almanca bilen kişiler üzerinde oluşan bu sosyal baskı neticesinde Almanca konuşma eğilimi gösterilmektedir. Bu eğilimin kadınlarda, Almanya doğumlularda ve birden fazla dil bilenlerde daha fazla olduğu tespit edilmiştir. Ayrıca Almanların olduğu sosyal ortamlarda Türklerin kendi aralarında da Almanca konuşmaları gerektiği düşüncesi en çok üçüncü nesil arasında yaygindır.

Almanya'da yaşayan Türklerin Türkçe hakimiyetleri de eskiye oranla gelişme göstermektedir. Türkçe Almanya'da canlılığını koruyan ve giderek daha aktif hal alan bir azınlık dili konumundadır. Katılımcılar Türkçeye hakimiyetlerinin iyi seviyede olduğunu belirtmektedirler. Türkçeye hakimiyette en üst sırada Türkiye'de doğmuş bireylerin geldiği görülmektedir. En az seviyede Türkçe hakimiyetine sahip olan grup ise Almanya doğumlu Türklerdir. Türkiye doğumlu bireylerin 
belli bir süre anavatanlarında yaşamış olmaları neticesinde doğal olarak Türkçeleri daha ileri seviyedir. Almanya'da doğup büyümüş olan üçüncü neslin ise Almancalarının Türkçelerinden daha iyi olduğu bilinmektedir (Kulaksızoğlu, 2008, s. 4). Elde edilen verilere göre Türkçeye hakimiyetleri yüksek olan yeni nesiller yoğun olarak Baden Würrtemberg eyaletinde yaşamaktadırlar. Yeni nesiller arasında Türkçeye en az hakimiyet ise Berlin eyaletinde yaşayanlara aittir. Evde arkadaşlarıyla ya da yalnız yaşayan bekar bireylerin Türkçeye hakimiyetleri evli ya da evde ailesiyle yaşayan kişilere oranla daha düşüktür. $\mathrm{Bu}$ durum Türkçenin aile ortamında pekiştirilerek daha canlı bir hal almasıyla alakalıdır. Ayrıca katılımcıların Almanya'da yaşadıkları süre arttıkça Türkçeye hakimiyetlerinde azalma olduğunu belirlenmiştir. Kulaksızoğlu'nun “Almanya'daki Üçüncü Kuşak Türk Gençlerinin Türkçe ve Almanca Bilme Seviyelerinin Bazı Değişkenler Açısından İncelenmesi ve Eğitim Sorunlarının Tartışılması" adlı çalışmasında da buna benzer bulgular mevcuttur. Almanya'da doğup büyüyen çocukların Türkçe ve Almancaları arasında hakimiyet farkı bulunması, bu çocukların Türkçe ve Almanca konuşulan ortamlarda bulunma süreleriyle alakalıdır (Sofu, 2002, s. 35). Almanya'da yaşayan yeni nesil Türklerin Türkçe hakimiyetleri düşüktür ve konuşurken sıklıkla hata yapmaktadırlar. Ayrıca Türkçe okuma yazma konusunda da yeni nesillerin sıkıntı yaşadıkları bilinmektedir (Nuruan vd., 2005, s. 59). Anne ve babanın dil bilme durumu bu noktada çok önemlidir. İki farklı dile sahip çiftlerin çocukları, içinde yaşadıkları toplumun hâkim dilini seçme eğilimi içindedirler (Çolak Bostanc1, 2014, s. 118). Ayrıca bireylerin vatandaşlık durumları da diğer maddelerde olduğu gibi Türkçeye hakimiyette de etkilidir. Alman vatandaşı olan bireylerin Almancaya daha çok hâkim oldukları bilinmektedir (Kulaksızoğlu, 2008, s. 4). Çocukları Alman vatandaşı olan katılımcılar yeni nesillerin Türkçeye yeterince hâkim olmadıklarını ve konuşurken sıklıkla hata yaptıklarını belirtmişlerdir.
Katılımcıların ağızlara bakış açısı incelendiğinde, genel itibariyle yaklaşımlarının olumlu olduğu görülmektedir. Almanya Türkleri arasında bölgesel ağızlar yaygın olarak kullanılmaktadır. $\mathrm{Bu}$ durumun oluşmasında, Almanya'ya Türkiye'nin birçok değişik bölgesinden işçilerin göç etmiş olması, diğer göç dalgalarında yine bu işçilerin Türkiye'de aynı bölgelerde yaşayan yakınlarının Almanya'ya gelmeleri, göçmen Türk gruplarının göç ettikleri yerlerde hemşericilik anlayışı ile beraber yaşamaları ve göçün ilerleyen safhalarında kurulan hemşeri derneklerinin büyük payı vardır. Katılımcılara göre bölgesel ağızların varlığı, o dilin zenginliğini göstermektedir. $\mathrm{Bu}$ olumlu tutum en yüksek oranla kendini Baden Würrtemberg eyaletinde göstermektedir. Ağız kullanımı da yine bu eyalette diğer eyaletlere göre daha fazladır. Ağızlara yaklaşımda, kişilerin vatandaşlık durumları ve doğdukları yer de etkilidir. Alman vatandaşı olanlar ile Almanya'da doğanların ağızlara karşı olumlu tutumu diğerlerine göre daha azdır. Ayrıca cinsiyet faktörü de bu konuda önemli bir etkendir. Almanya Türkleri arasında kadınlar erkeklere oranla daha az düzeyde ağızların dilsel zenginlik olduğunu düşünmektedirler. Eğitim seviyesi ve birden fazla dil yetkinliğine sahip olma durumu, kişilerin dil bilinçlerinin artmasını sağladığı gibi ağızlara yaklaşımlarında da olumlu bir etken durumundadır. Üniversite mezunları ve birden fazla dil bilen bireyler, diğerlerine göre daha yüksek oranda ağızların dilsel zenginlik olduğunu belirtmişlerdir. Kuşaklar arası fark ele alındığında ise birinci ve ikinci neslin ağızlara yaklaşımı üçüncü nesle oranla daha olumludur. Yeni nesiller bölgesel ağızları daha az kullanmaktadırlar. Türkiye'nin çeşitli bölgelerinden Almanya'ya gelen birinci nesil, ikinci nesle ev ortaminda bölgesel ağız özelliklerini barındıran Türkçeyi ana dil olarak öğretmiştir. Göçün ilk dönemlerinde, Almanya'da Türklerin Türkçe yayın yapan televizyon ve radyoları takip etmesi, Türkçe yayımlanan gazete, dergi ve kitaplara ulaşması oldukça güçtü. $\mathrm{Bu}$ durum onların İstanbul Türkçesini benimseyerek ağız özelliklerinden arınmış bir Türkçeye sahip olabilmelerinin önüne geçmiş ve ağız kullanımını Almanya'da canlı tutmuş̧tur. $\mathrm{Bu}$ nedenle ilk iki neslin Türkçesi, 
yaygın olarak ağız özelliklerine sahiptir. Üçüncü nesil ise Türkçe yayın yapan televizyon ve radyoları rahatlıkla takip edebilmekte, Türkçe gazete, dergi ve kitapları okuyabilmektedir. $\mathrm{Bu}$ durum günümüzde yeni nesiller arasında ağızlara karşı farklı bir tutumun gelişmesine neden olmuştur. Ağızlara karşı oluşan bu yeni yaklaşım, gelecekte Almanya'da ağız özelliklerinin kaybolması ihtimalini de beraberinde getirmektedir.

Bireyler, dil edinimlerini ait oldukları dilsel topluluklar vasitasıyla elde ederler. Toplumlar bireylerine sahip oldukları dili öğretirler (Zeyrek, 2003, s. 27). Dil yitimi; bireylerin ya da toplulukların sahip oldukları dili kullanmayı bırakarak başka bir dili kullanmaya başlamaları durumunda, bir dilin yerini başka bir dile bırakması sonucu ortaya çıkmaktadır (İmer vd., 2011, s. 88). Ana dilin, göç edilmiş olan ülkenin diline göre değersiz görülmesi gibi çeşitli nedenlerden dolayı birey ya da toplulukların kendi ana dillerini kullanmayı bırakarak hâkim topluluğun dilini kullanmaya başlamasına dilsel kayma ad1 verilir (İmer vd., 2011, s. 88; Alpay, 2010, s. 87). Almanya'da yaşayan birinci nesil, ana dillerini Türkiye'de Türk toplumu içinde öğrenmişlerdir. Bu durum, birinci neslin dil yitimi tehlikesinden korunmasını sağlamıştır. Kişi ya da topluluklar, dillerinin değersiz olduğuna ve sosyal işlevi kalmadığına inanmaya başladıkları zaman, o kişi ya da topluluklarda dil yitimi başlamaktadır (Alpay, 2010, s. 87; Johanson, 2009, s. 54). Araştırmaya katılan birinci nesil Türkler, Almanya'da Türkçenin kaybolmayacağını ve gelecekte yeni nesillerin ana dillerinin Almanca olmayacağını düşünmektedirler. Baden Würrtemberg eyaletinde bu eğilim oldukça yüksektir. Bunun temel sebebi, Türkçenin sosyal hayatta en çok Baden Würrtemberg eyaletinde aktif olarak kullanılması, değerli, işlevsel ve gerekli bir unsur olarak görülmesidir. Elde edilen bulgulara göre doğulan ülke ve vatandaşlık durumu dil yitiminde oldukça etkilidir. Türkiye doğumlu bireyler, yüksek oranlarla, gelecekte Almanya'da dil yitimi yaşanmayacağını savunmaktadırlar. Bu noktada en düşük oran ise Alman vatandaşı olan katılımcılara aittir. Ayrıca eşlerin vatandaşlık durumları da bu konuda etkilidir. Eşi Alman vatandaşı olan kişiler, Almanya'da Türkçenin kaybolmayacağı düşüncesine, eşi Türk vatandaşı olan katılımcılara göre daha az oranla sahiptir. Ayrıca kişilerin dil bilme durumları ve aylık gelir seviyeleri de Almanya'da Türkçenin yitimi konusundaki tutumlarda etkilidir. Birden fazla dil bilen ve yüksek gelir seviyesine sahip kişiler, sadece Türkçe konuşabilen ve gelir seviyesi düşük kişilere göre daha yüksek oranlarla Almanya'da dil yitimi yaşanabileceğini düşünmektedirler. $\mathrm{Bu}$ durum eğitimli ve yüksek gelir seviyesine sahip Türklerin, eğitim seviyesi düşük ve dar gelir grubuna ait olanlara oranla daha fazla hâkim kültürü benimsemeye eğilimli olmalarından kaynaklanmaktadır (Halman'dan aktaran Çolak Bostanc1, 2014, s. 109).

Ana vatanlarından ayrılarak başka bir ülkede yaşamaya başlayan göçmenler arasında dil yitiminin en sık görüldüğü nesil üçüncü nesildir. Ana dil, göç edildikten sonra ilk iki nesle tam olarak aktarılabilirken, üçüncü nesil ile dil yitimi başlayabilmektedir (Castles ve Miller, 2008, s. 360). Ama bu durum Almanya Türkleri için söz konusu değildir. Her ne kadar birinci nesil Türklerin küçük bir kısmı, gelecek nesillerin Türkçeyi unutacağından ve ana dillerinin Almanca olacağından kaygı duyduklarını belirtmiş olsalar da üçüncü nesil Türkler buna karşı çıkmış ve dillerini unutmayacaklarını ve de ana dilleri olarak sadece Almancayı kabul etmeyeceklerini belirtmişlerdir. $\mathrm{Bu}$ durum yetişen genç nesillerde ana dil bilincinin oluşmaya başladığını göstermektedir. Buna benzer bir durum da yeni nesillerin Türk Edebiyatı ve yazarlarına karşı yaklaşımlarında ortaya çıkmaktadır. Katılımcıların çoğunluğu yeni nesillerin Türk Edebiyatı ve yazarlarını iyi bilmediklerini düşünmektedir. Birinci nesil yüksek oranlarla bu düşünceye katılırken üçüncü nesil Türklerde bu oran daha düşüktür. Türkçe, Almanya'da diğer göçmen dilleri arasında en canlı ve dinamik olan dildir ve uzun vadede de yok olmayacağı ortadadır (Yağmur, 2010, s. 226-238).

Almanya'da yaşayan Türkler günümüzde çağın getirdiği imkanlar sayesinde rahatlıkla Türkçe 
yayın yapan televizyon ve radyo kanallarını takip edebilmekte ve Türkçe basılan gazete, dergi ve kitaplara sorunsuz ulaşabilmektedir. Ayrıca içinde yaşadıkları Alman toplumunun okuma seviyesinin yüksek olması da Almanya Türklerinin Türkiye Türklerine oranla daha fazla okuma eğilimi göstermelerine sebep olmaktadır (Şen, Öz ve İyidirli, 1996, s. 36). Almanya Türkleri aktif olarak Türkçe yayınları takip etme eğilimi göstermektedir. $\mathrm{Bu}$ durum onların dillerini ve kültürlerini koruma refleksiyle alakalıdır (Baş, 2014, s. 83). Baden Würrtemberg eyaletinde yaşayan, Türkiye doğumlu, üniversite mezunu ve evli olan kişilerde Türkçe yayınları takip etme eğilimi en üst düzeydedir. En az eğilim ise Berlin eyaletinde yaşayan ve Alman vatandaşlı̆̆ına sahip kişilerde görülmektedir. Ayrıca Almanya'da yaşanılan süre arttıkça Türkçe yayınlara eğilim de artmaktadır. Bu eğilim en çok birinci nesilde, en az ise üçüncü nesilde görülmektedir. Türklerin Türkçe yayınları takip ediyor olması etnik bilinçlerinin de yüksek olmasını sağlamaktadır (Yüksel, 2008, s. 204-208).

Dil ve Entegrasyon bağlamında ise katılımcılar; asimilasyon amacı gütmeyen, onları dil, din, milliyet ve kültürleriyle benimseyebilecek bir toplumsal birleşime olumlu tutum sergilemektedirler. Alman toplumundan kopuk izole bir hayatın her iki toplum için de faydasız olduğu fikri günümüzde artık Türk toplumu arasında yaygınlık kazanmaktadır. Bu noktada katılımcıların büyük çoğunluğu Almancaya hakimiyetin çok önemli olduğunu düşünmektedirler. Söz konusu eğilim en yüksek katılımla Berlin'de, en düşük oranla ise Baden Würrtemberg eyaletinde görülmektedir. Son olarak kadınların erkeklere, Almanya doğumluların Türkiye doğumlulara, üniversite mezunlarının ilkokul mezunlarına, birden fazla dil konuşabilen kişilerin sadece Türkçe konuşabilenlere ve üçüncü neslin diğer nesillere oranla Alman toplumuyla birlikte yaşamaya daha olumlu yaklaştıkları bu araştırmada ulaşılan sonuçlar arasındadır.

\section{Kaynakça}

Abadan Unat, N. (2002). Bitmeyen Göç Konuk Iş̧̧̧ilikten Ulus Ötesi Yurttaşlı̆̆a. İstanbul: Bilgi Yayınevi.

Adıgüzel, Y. (2004). Kimliğin Korunmasında ve Üretilmesinde Türk Derneklerinin Rolü Almanya / Köln Örneği (Doktora Tezi). Ulusal Tez Merkezi veri tabanından alınmıştır. (148472).

Akarsu, B. (1984). Wilhelm von Humboldt'ta Dil-Kültür Bağlantısı. İstanbul: Remzi Kitabevi.

Akkaya, B. (2011). Almanya'da Yaşayan Türklerin Kültürel Sorunları. F. Şen (Ed.), 50. Yllında Gö̧̧ (ss. 199-207). Ankara: Kültür ve Turizm Bakanlığı Yayınları.

Alkan, N. M. (2011). Yeni Bir Fenomen Olarak Çift Yönlü Göç. F. Şen (Ed.), 50. Yılında Göç (ss. 180-193). Ankara: Kültür ve Turizm Bakanlığı Yayınları.

Alpay, N. (2010). Anadili, Yabancı Dil ve Eksiltici İkidillilik. Ankara: Eğitim-Sen Yayınları.

Arayıcı, A. (2002). Türkiye'den Avrupa'ya Göçün 40 Yllı. İstanbul: Ceylan Yayınları.

Aslan, A. (1996). Otuzbeş Ylllık Göç ve Almanya'daki Türkler. Durum Raporu.

Balc1, A., Uyar, Y. ve Büyükikiz, K.K. (2012). İlköğretim 6. Sınıf Öğrencilerinin Okuma Alışkanlıkları, Kütüphane Kullanma Sıklıkları ve Okumaya Yönelik Tutumlarının İncelenmesi. Turkish Studies, 7(4), 965-985.

Baş, N. (2014). Federal Almanya'da Yayımlanan Türkçe Günlük Gazetelerin Dil Kullanımı Üzerine. Bilig, 70, 81-104.

Bavelas, J. \& Gerwing, J. (2007). Conversational Hand Gestures and Facial Displays in Face-to-Face Dialogue. Social Communication, 283-308. https://www.researchgate.net/publication/291346620 adresinden erişilmiştir.

Castles, S. \& Miller, M. (2008). Göçler Çăğ-Modern Dünyada Uluslar Arası Göç Hareketleri. İstanbul: Bilgi Üniversitesi Yayınları.

Crystal, D. (1992). An Encyclopedic Dictionary of Language and Languages. Cambridge: Blackwell.

Çil, H. (2011). Yarım Asır Önce: 1961 İşçigücü Alımı Anlaşmasına Analitik-Eleştirel Bir Bakış. F. Şen (Ed.), 50. Yılında Göç, (ss.41-50). Ankara: Kültür ve Turizm Bakanlığı Yayınları.

Çolak Bostancı, G. (2014). Amerika'daki Birinci ve İkinci Kuşak Türklerin Dil Tercihleri, Sürdürümleri, Tutumları ve Etnik Dilsel Canlılıkları. Bilig, 70, 105-130.

Eker, S. (2007). Toplum-Dilbilim, Dil Planlamaları ve Kamu Mensuplarının Dil Kullanımı. Gazi Türkiyat, 1, 127-135. 
Ercan, S.G. \& Yağcıoğlu, S. (2007). Gazete Köşe Yazılarında Kaçınma Kullanımı ve Cinsiyet İlişkisi. Dilbilim Araştırmaları, 1-16.

Faist, T. (2003). Ulusaşırı Göç ve Ulusaşırı Toplumsal Alanlar. (A.Z. Gündoğan \& C. Nacar, çev.). İstanbul: Bağlam Yayınc1lık.

Göksu, T. (2000). İşçilikten Vatandaşlı̆̆a: Almanya'daki Türkler. Ankara: Özen Yayıncılık.

Göktuna Yaylacı, F. (2012). Belçika'daki Türklerin Dil Kullanımları. Uşak Üniversitesi Sosyal Bilimler Dergisi, 5(2), 63-88.

Grosjean, F. (1982). Life with Two Languages: An Introduction to Bilingualism. Mass: Harvard University Press.

Heger, B. (2010). Soziolinguistische Überlegungen zum Phänomen Bastian Sick: Die Diskussion in Info DaF oder eine neuerliche Kontroverse um Defizit- und Differenzhypothese. Norderstedt: GRIN Verlag.

İmer, K., Kocaman, A. \& Özsoy, S. (2011). Dilbilim Sözlügüu. İstanbul: Boğaziçi Üniversitesi Yayınevi.

Johanson, L., (2009). Türk Dili Haritası Üzerinde Keşifler. (N. Demir \& E. Yılmaz, çev.) Ankara: Grafiker Yayınları.

Karagöz, R. (2001). Yaban Sıla Oldu: Türkiye'den Almanya'ya Göçün 40. Yı11, Tezkire Dergisi, 19-25.

Kartal Doyuran, B. (2004). Dış Göç Sürecinde Türk Kadınlarının Durumu: Almanya'daki Türk Kadın Göçmenler. Kadın Çalışmalarında Disiplinlerarası Buluşma Sempozyum Bildiri Metinleri. İstanbul: Yeditepe Üniversitesi Yayınları.

Kilıçaslan, E. (2006). Almanya'daki Türklerin Türk-Alman Iliş̧kileri Açısından Önemi ve Türk Nüfusunun Etkinliğinin Artırılmasına Yönelik Alınabilecek Tedbirler. Yayınlanmamış Yüksek Lisans Tezi. Atılım Üniversitesi, Sosyal Bilimler Enstitüsü, Ankara.

Kipp, S., Clyne, M. \& Pauwels, A. (1995). Immigration and Australia's Language Resources. Canberra: The Australian Government Publishing Service (AGPS).

Kocaman, A. \& Osam, N., (2000). Uygulamalı Dilbilim Yabancı Dil Öğretimi Terimleri Sözlüğ̈̈. Ankara: Hitit Basım Yayın.

Köksal, S., (1986). Refah Toplumunda Getto ve Türkler. İstanbul: Tegnografik Matbaacilık.

König, G. (1992). Dil ve Cins: Kadın ve Erkeklerin Dil Kullanımı, Dilbilim Araştırmaları Dergisi, 25-36.

Kulaksızoğlu, A. (2008). Almanya'daki Üçüncü Kuşak Türk Gençlerinin Türkçe ve Almanca Bilme Seviyelerinin Bazı Değişkenler Açısından İncelenmesi ve Eğitim Sorunlarının Tartışılması. Dokuz Eylül Üniversitesi Buca Eğitim Fakültesi Dergisi, 23, 1-6.

Myers Scotton, C. (2006). Multiple Voices: An Introduction to Bilingualism. Malden: Blackwell Publishing.
Nuruan, M., Güneş, T., Beder Şen, R., Güneş, S., Kalaycı, A.R. \& Kaplan, M. (2005). Federal Almanya'da Yaşayan Türklerin Aile Yapısı ve Sorunları Araştırması. Ankara: Aile ve Sosyal Araştırmalar Genel Müdürlüğü.

Öztürk Dağabakan, F. (2012). Toplumdilbilimsel Bir Kavram Olarak Kadın Erkek Dil Ayrımına Türkçe ve Almanca Açısından Bir Yaklaşım, Atatürk Üniversitesi Türkiyat Araştırmaları Enstitüsü Dergisi, 47, 87-106.

Parekh, B. (2002). Çok Kültürlülüğü Yeniden Düşünmek Kültürel Çeşitlilik ve Siyasi Teori. Ankara: Phoenix Yayınlar1.

Ryan, E. B., Giles, H. \& Sebastian, R. J. (1982). An Integrative Perspective for the Study of Attitudes Toward Language Variation. In Attitudes Towards Language Variation: Social and applied contexts, Ellen Bouchard Ryan and Howard Giles (eds), (ss.1-19). London: Edward Arnold.

Sofu, H. (2002). Sesletim İşlemleri: İngilizce ve Türkçe Edinen İki Dilli Bir Çocuktan Örnekler. Dilbilim Araştırmaları, 27-36.

Şahin, B. (2010). Almanya'daki Türkler Misafir İşçilikten Ulusötesi (Transnasyonel) Bağların Oluşumuna Geçiş Süreci. Ankara: Phoenix Yayınevi.

Şen, F., Öz, G. \& İyidirli, A. (1996). Federal Almanya'da Yaşayan Türklerin Kültürel Sorunları ve Çözüm Yolları. Köln: Önel Verlag.

Şen, F. \& Goldberg, A. (2004). Die Deutschen Türken. Essen: Önel Verlag.

Şen, F., Ulusoy, Y. \& Öz, G. (1999). Avrupa TürkleriFederal Almanya ve Diğer AB Ülkelerinde Çalışan Türklerin Ekonomik Gücü. İstanbul: Cumhuriyet Yayınları.

Taşdelen, M., Sözen, E., Duran, H. \& Eskicumal1, A. (2000). Avrupa'da Yeni Kuşak Türk Gençliği (Kimlik ve Uyum Sorunlarl). Sakarya: Sakarya Üniversitesi Yayınları.

Tekin, H. \& Hasskamp, L. (2011). Türklerin Geri Dönüşü. F. Şen (Ed.), 50. Yılında Göç (ss. 167-179), Ankara: Kültür ve Turizm Bakanlığı Yayınları.

Thurstone, L. L. (1928). Attitudes can be Measured. The American Journal of Sociology, 33, 529-554.

Yağmur, K. (2010). Batı Avrupa'da Uygulanan Dil Politikaları Kapsamında Türkçe Öğretiminin Değerlendirilmesi. Bilig, 55, 221-242.

Yağmur, K. \& Akıncı, M.A. (2003). Language use, choice, maintenance, and ethnolinguistic vitality of Turkish speakers in France: Intergenerational differences. International Journal of the Sociology of Language, 107-128.

Yalınkılıç, K. (2013). Bulgaristan Kırcaali Türklerinin Dil Durumu - Toplumdilbilimsel Bir Inceleme. Yayımlanmamış Doktora Tezi. Ondokuz Mayıs Üniversitesi, Sosyal Bilimler Enstitüsü, Samsun. 
Yalınkılıç, K. \& Yağmur, K. (2014). Batı Trakya Türklerinin Anadillerine ve Kültürlerine Karşı Tutumları. Bilig, 70, 283308.

Yıldız, C. (2012). Yurt Dışında Yaşayan Türk Çocuklarına Türkçe Öğretimi (Almanya Örneği). Ankara: Yurtdışı Türkler ve Akraba Topluluklar Başkanlığı Yayınları.

Yüksel, Ö. (2008). Türkiye'den Amerika Birleşik Devletleri'ne Göç Eden Birinci Kuşak Göçmenlerin Yararlandı̆̆ Kitle İletişim Ortamlarının Ulusaşırı Kimlik

Dönüşümüne Etkileri. (Yayımlanmamış Doktora Tezi). Anadolu Üniversitesi, Sosyal Bilimler Enstitüsü, Eskişehir.

Zeyrek, D. (2003). Söylem ve Toplum- Söylem Üzerine. Ankara: ODTÜ Yayınları. 